\title{
Piezoelectric ceramic for energy harvesting from ambient vibration
}

\author{
Musaab Zarog \\ Department of Mechanical \\ and Industrial Engineering, \\ College of Engineering, \\ Sultan Qaboos University, \\ P.O. Box 33, Al-Khod, Muscat, \\ 123 Sultanate of Oman \\ Email:musaabh@squ.edu.om
}

\begin{abstract}
Direct piezoelectric conversion is very popular in generating power from mechanical stress. There is continuous progress in power harvesting from mechanical vibration. In this article, experimental tests on a piezoelectric circular plate, to evaluate the electric power produced by the piezoelectric conversion at low acceleration over a wide range of ambient vibration frequency, are presented. The experimental analysis is presented and discussed. The results demonstrate the potentiality of using low-cost piezoelectric diaphragms to harvest energy from ambient vibration. Under low acceleration $\left(5.36 \mathrm{~m} / \mathrm{s}^{2}\right)$, the vibration frequency was varied in the range of 10 $200 \mathrm{~Hz}$ and the generated power was measured. Under a very small dynamic force (less than $0.06 \mathrm{~N}$ ), the output power of $1.5 \mathrm{~mW}$ was obtained with an $8.5 \mathrm{~mm}$ drum harvester across a load resistance of $17.8 \mathrm{k} \Omega$ at a frequency of $173 \mathrm{~Hz}$.
\end{abstract}

Keywords: vibration energy, diaphragm, PZT, mechanical vibration, ceramics, vibration frequency, resonance, full-wave rectifier

\section{INTRODUCTION}

There is an on-going decrease in the size and low-power requirements of today's portable electronic devices that mainly work on batteries. Despite this reduction in the required power, the issue that the batteries used in these low power electronics need to be replaced from time to time remains. It is now more appealing to replace batteries in some low-power devices (e.g., network sensors) with self-power generators that utilize free and clean ambient energy from the environment, especially in areas that are hard to access. Other that solar energy, one promising source of free energy is the ambient vibration energy. Converting ambient vibration to energy can be realised using different conversion principles (e.g., piezoelectric, electro- magnetic, and electrostatic) with the piezoelectric-based devices being the highest power density generators. Piezoelectric generators are based on conversion of mechanical strain to electrical energy. Research in piezoelectric energy harvesting is developing rapidly with the main aim to increase the output power $[1,2]$. Among the piezoelectric materials, piezoceramics are an excellent candidate to be used since they are relatively affordable and provide good electromechanical coupling [3]. The most commonly produced piezoelectric ceramics are lead zirconate titanate (PZT). Most of research focuses on MEMS cantilevered-shape energy harvesters from mechanical vibration [4]. To achieve maximum power, these micro-cantilevers have to vibrate at their resonance frequencies, which present another challenge: their resonance 
frequencies do not match ambient vibration [2]. At the macro scale level and despite the high produced power, the use of piezoelectric ceramic is mainly limited to static loading due to their inflexibility. Nevertheless, some research has paid attention to power generation from dynamic loads via macro piezoceramics.

Sheng Wang et al. reported $11 \mathrm{~mW}$ power generated from drum transducer at a resonance frequency of $590 \mathrm{~Hz}$ across a load of $18 \mathrm{k} \Omega$, under a pre-stress of $0.15 \mathrm{~N}$ and cyclic stress of $0.7 \mathrm{~N}$ [5]. Palosaari et al. also reported about harvested power with different force biases (between 0 to $22.5 \mathrm{~N}$ at compression cycles at $0.96 \mathrm{~Hz}$ ) using $0.2 \mathrm{~mm}$ thick PZ-5A piezoelectric ceramic disc

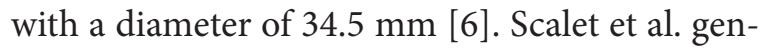
erated power from a commercial ceramic buzzer through load pressure at frequency of $2 \mathrm{~Hz}$ [7]. The aforementioned work presents power generation from very low pressure (less than $3 \mathrm{bar}$ ). A more similar work was carried out by Yang [8], where authors used four piezoelectric ceramic disks to generate $28 \mathrm{~mW}$ power at $150 \mathrm{~Hz}$ under a pre-stress of $0.8 \mathrm{~N}$ and a vibration acceleration of $9.8 \mathrm{~m} / \mathrm{s}^{2}$. Another group reported a $12 \mathrm{~mW}$ generated under an acceleration of $9.8 \mathrm{~m} / \mathrm{s}^{2}$, a prestress of $1.2 \mathrm{~N}$ applied at the resonance frequency of the harvester $(113 \mathrm{~Hz})$ across a $33 \mathrm{k} \Omega$ resistor [9]. A large drop in the output power was reported when the array was derived at frequencies other than $150 \mathrm{~Hz}$ (the resonance frequency of the energy harvesting array). This will also limit its use for a wide range of ambient vibration. The aim of this work - beside using affordable PZT piezoceramics at low vibration frequencies - is to demonstrate their capabilities of producing high power at wide range of frequencies other than their fundamental resonance of the commercial piezo buzzer. A low cost commercially available piezo buzzer (Fig. 1) was chosen for this study. The buzzer is provided with two wires: one wire is welded onto the metal plate and the other wire on the piezoelectric disk. In this work, it will be used to produce relatively high power at wide range of low frequencies (far away from its resonance value of approximately $4500 \pm 500 \mathrm{~Hz}$ ).

\section{Theoretical background}

A piezoelectric material generates a voltage proportional to applied tension or compression.

Electrical charge produced when mechanically deformed is governed by the following equations:

$$
\begin{aligned}
& \delta=\frac{\sigma}{Y}+d E, \\
& D=\epsilon E+d \sigma
\end{aligned}
$$

where $\delta$ is the mechanical strain, $\sigma$ is the mechanical stress, $Y$ is the modulus of elasticity (Young's modulus), $d$ is the piezoelectric strain coefficient, $E$ is the electric field, $D$ is the electrical displacement (charge density), $\in$ is the dielectric constant, and $d \sigma$ is the dielectric constant.

The piezoelectric circular plate can be modeled as a spring-mass-damper system. The equation governs the free vibration behaviour; a second order differential equation can be written as:

$$
m \frac{d^{2} z(t)}{d t^{2}}+b \frac{d z(t)}{d t}+k z(t)=m \frac{d^{2} y(t)}{d t^{2}}
$$

where $m$ is the effective mass, $b$ is the damping coefficient, and $k$ is the structure stiffness.

The maximum strain occurs at the resonance frequency of the vibrated structure. The resonance frequency of a circular plate can be calculated using the following equation [10]:

$$
f_{r}=\frac{\lambda_{n}^{2} t}{2 \pi r^{2}} \sqrt{\frac{E}{12 \rho\left(1-v^{2}\right)}},
$$

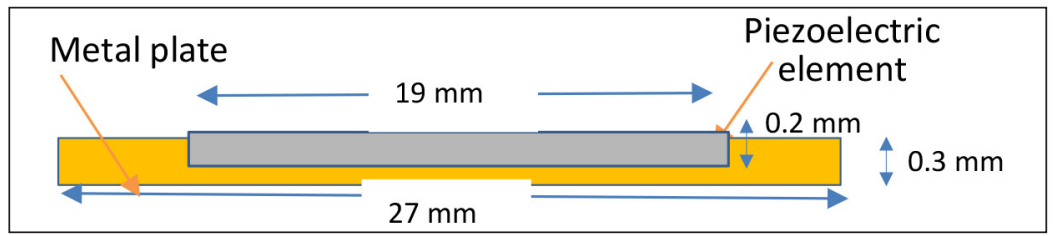

Fig. 1. PZT Ceramic buzzer used from Murata Co 
where $E$ is average Young's modulus $(\mathrm{Pa}), v$ is the average Poisson's ratio of the circular plate, $\rho$ is its average density $\left(\mathrm{kg} / \mathrm{m}^{3}\right), t$ is its thickness $(m)$ and $r$ is the radius of the circular plat, $\lambda_{n}$ is the resonance eigenvalue, where $\mathrm{n}$ denotes the resonance mode, i.e., first mode $\lambda 1=3.196$. Whenever possible, it is always advisable to vibrate the structure at its calculated resonance frequency for maximum power generation.

\section{Experimental setup}

The scheme and apparatus for experimental setup are shown in Fig. 2. The shaker (Brüel \& Kjær Instruments, model type 4810) was used to drive the structure at various frequencies using a function generator (IDL-800A). The output voltage from the structure and the vibration acceleration was monitored by a digital oscilloscope (Owon smart DS $7102 \mathrm{~V}$ ). The piezoceramic was glued to the vibrating element of the shaker. To obtain the largest deformation of the piezo element and hence the largest generated voltage, the piezo disc has to be vibrated at its resonance frequency which can be calculated from equation (4). A $4.5 \mathrm{kHz}$ resonance frequency is reported by the piezoceramic manufacturer. Since our aim here is to generate power from ambient vibration (less than $200 \mathrm{~Hz}$ ), it is impractical to operate the structure at its res-

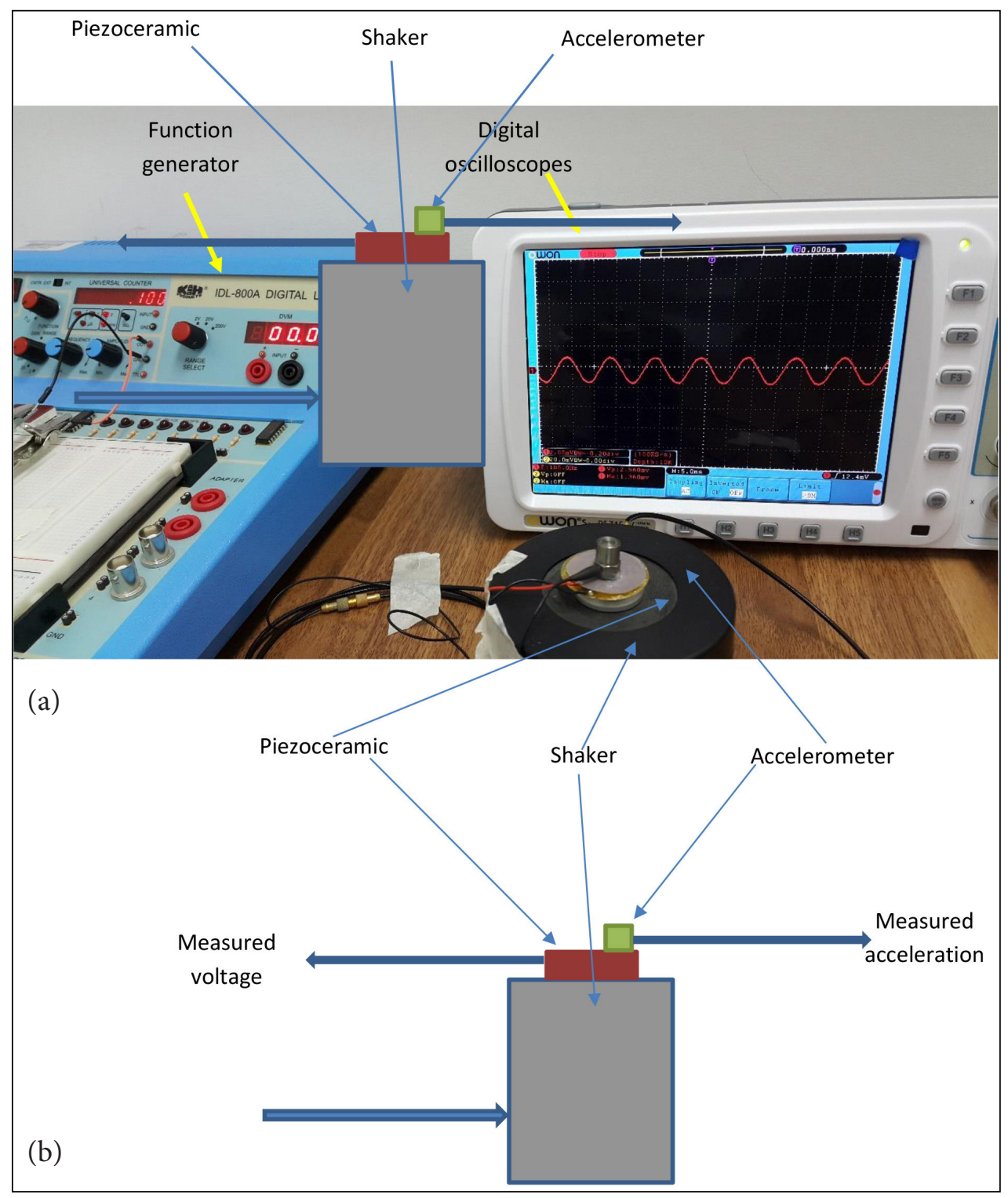

Fig. 2. Experimental setup: $a$ - apparatus, $b$ - the scheme 
onance frequency (although it is expected to be less than $4.5 \mathrm{kHz}$ due to the prestressing effect). Alternatively, the piezo structure was vibrated at a low-frequency range (far lower than its resonance frequency).

\section{RESULTS AND DISCUSSION}

The amount of voltage generated will depend on the stress and strain distribution and hence on the clamping conditions of the piezo structure. A random initial clamping by simple gluing of the structure to the vibrating element (in the shaker) resulted in output voltage presented in Fig. 3.
The output voltage (peak-to-peak) was measured at no load over a wide range of low frequencies. It can be seen from the results that the maximum generated voltage is lower than $0.7 \mathrm{~V}$. To generate a higher output voltage, the pre-stress was introduced by fixing the piezo structure to the shaker using adhesive tape as shown in Fig. 4. At different excitation frequencies, hence generated voltage was improved as shown in Fig. 5. Pre-stressing the structure acted as a proof mass. It is known that the pre-stress of the piezoelectric element enhances the output power of the energy harvester $[6,8,9]$.

The output voltage (V) from piezoceramic buzzer was measured across a variable resistance

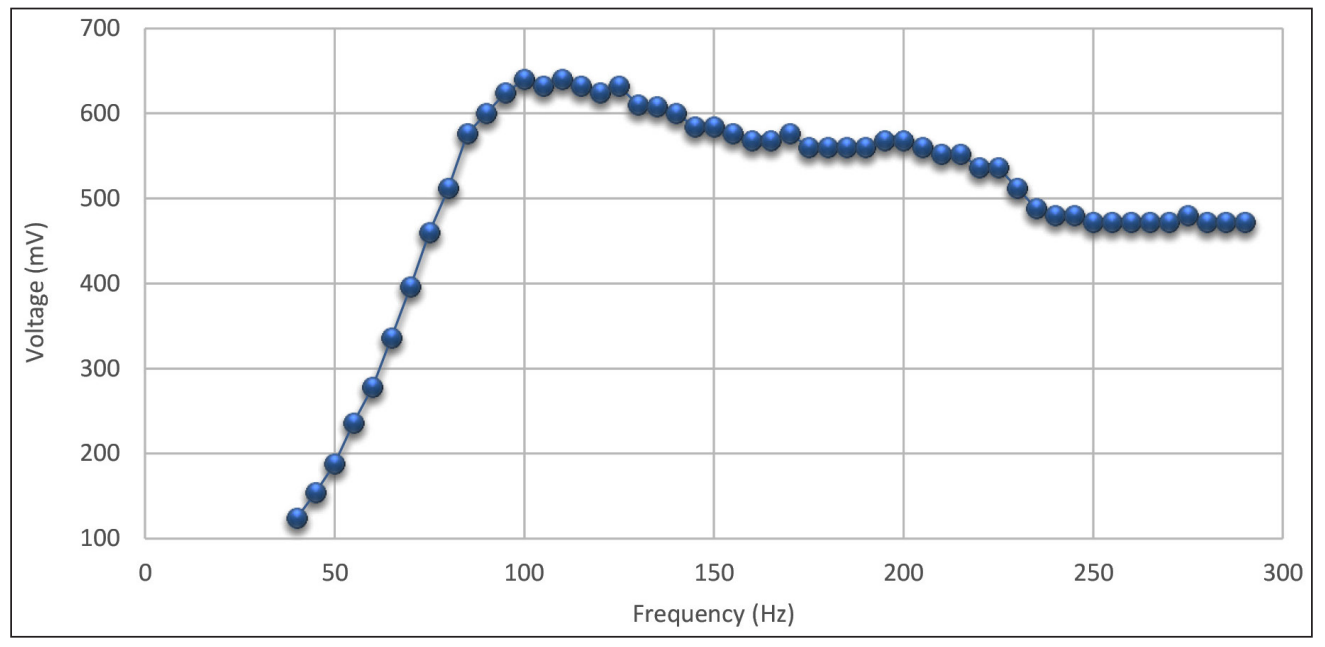

Fig. 3. Generated voltage as a function of the vibration frequency with initial clamping (without pre-stress)

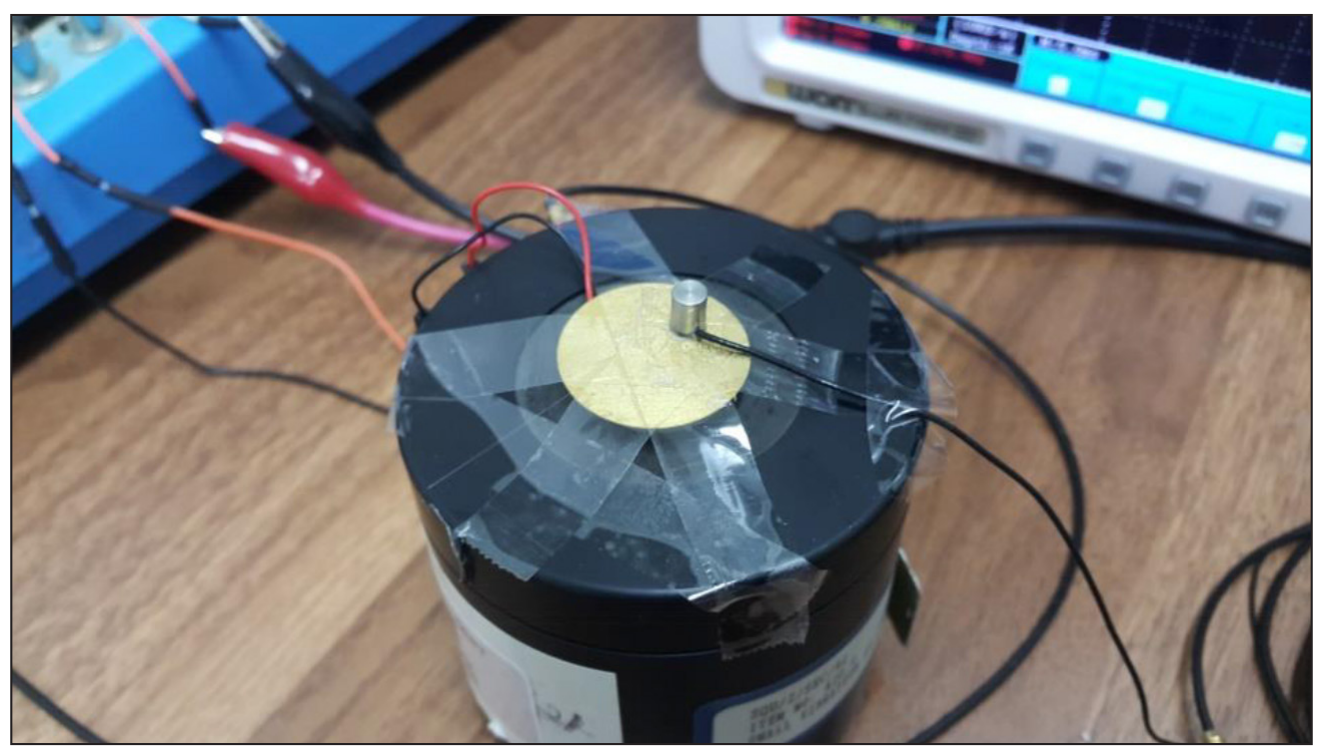

Fig. 4. Altered clamping and pre-stressing 


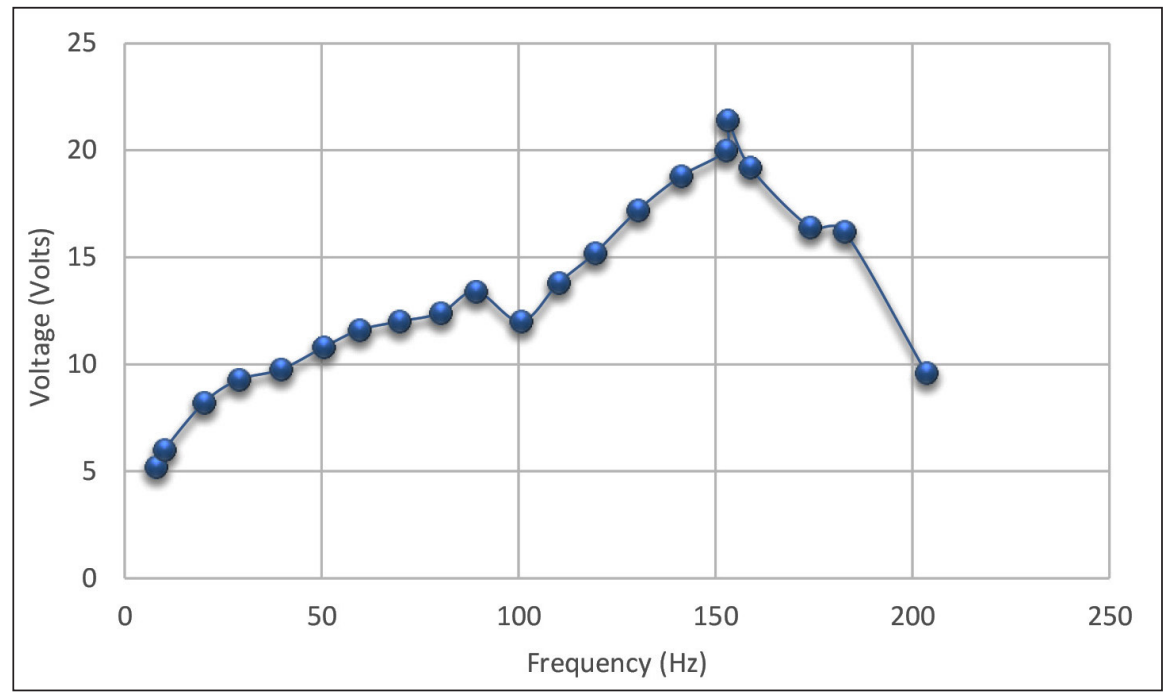

Fig. 5. Generated voltage as a function of the vibration frequency with altered clamping

(R) using a digital oscilloscope. Averages of 16 readings were taken for each output voltage. As it is presented in Fig. 5, the highest generated voltage was measured at $171 \mathrm{~Hz}$. Hence, the electric power (at frequency $171 \mathrm{~Hz}$ ) consumed by the load resistor was calculated using equation:

$$
P=\frac{V^{2}}{R}
$$

The variation of power generated against the load resistance is shown in Fig. 6, which indicates that the maximum power is obtained at the range between 10 to $20 \mathrm{k} \Omega$. According to Thévenin's theorem, maximum power occurs when the load is equal to the internal resistance. To validate this result, the internal resistance (equivalent impedance of the piezo structure) was measured and it was found to be $17.8 \mathrm{k} \Omega$ (which is in the range of power peak). A slightly higher power was obtained when the load was set exactly to $17.8 \mathrm{k} \Omega$ and it was found to be $1.5 \mathrm{~mW}$. This power was obtained at $171 \mathrm{~Hz}$ at an acceleration of $5.63 \mathrm{~m} / \mathrm{s}^{2}$. Under this acceleration and at a frequency as low as $10 \mathrm{~Hz}, 8 \mathrm{~V}$ can be achieved

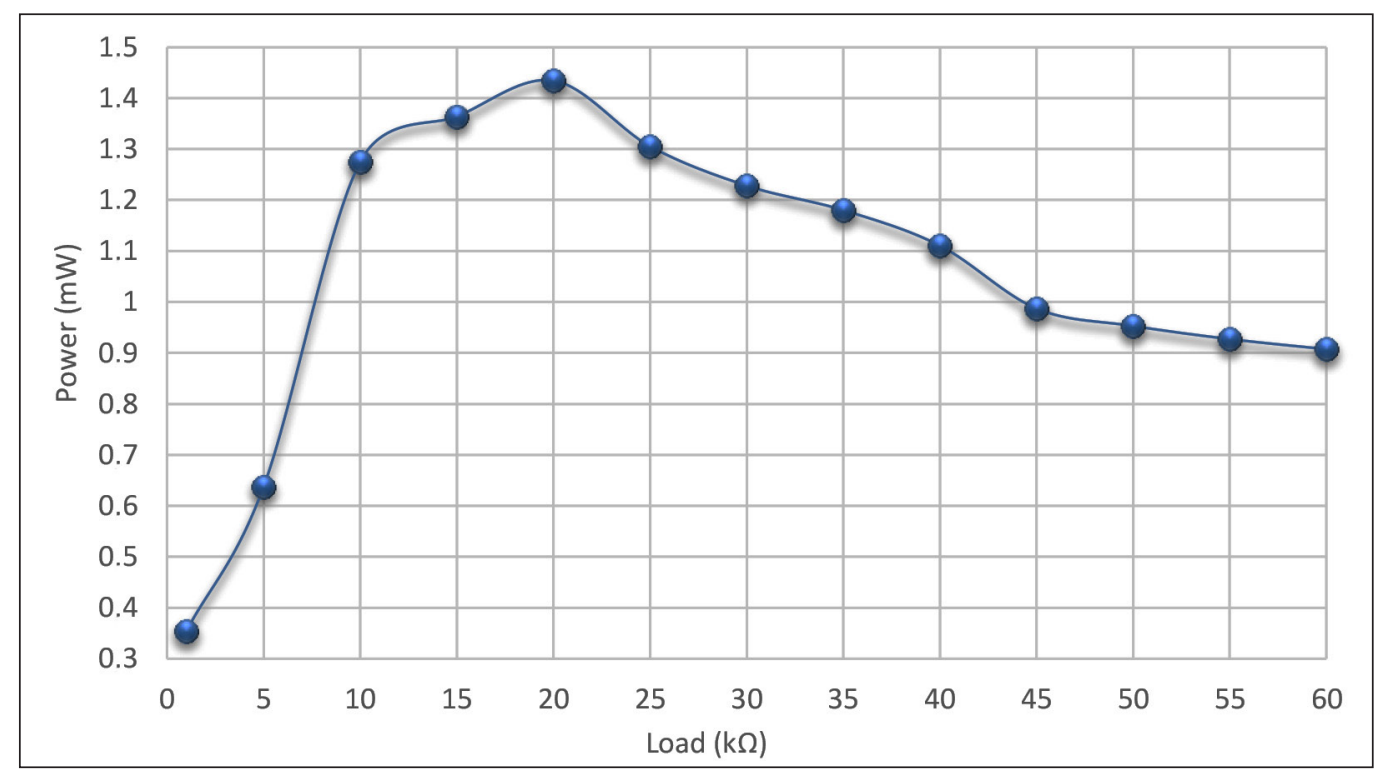

Fig. 6. Power outputs against load resistances 


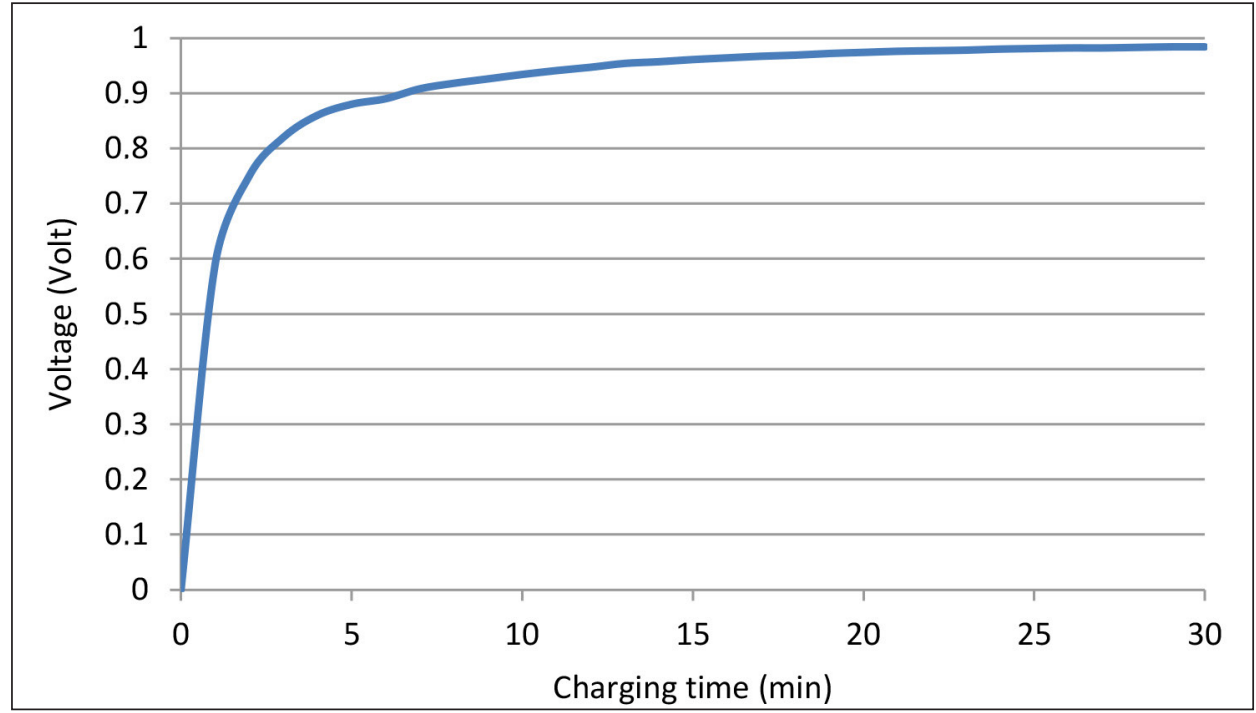

Fig. 7. Charging time for $1000 \mu \mathrm{F}$ capacitor

at no load which indicates promising potential energy. Newton's second law was applied to calculate the driving force which was found to be very small (less than $0.06 \mathrm{~N}$ ). For real-world applications of vibration energy harvester with piezoelectric materials, the generated AC current needs to be converted to DC current, which can be used later to charge a battery of an electronic device. Alternatively, the rectified voltage can be stored in a capacitor for later use to power a device. Also, from a practical point of view, the rectified voltage could have ripples that need to be filtered before powering a load with a DC voltage. This can be achieved by adding a filter capacitor. To check the potentiality of using the structure for charging purposes, the generated AC voltage was converted to DC voltage. The output signal of the piezoelectric harvester (PEH) was rectified by a conventional full bridge rectifier (using four Schottky diodes) to charge a $1000 \mu \mathrm{F}$ capacitor. The PEH can charge the capacitor of $0.6 \mathrm{~V}$ after $1 \mathrm{~min}$ as shown in Fig. 7. This result is promising for charging batteries for portable devices.

\section{CONCLUSIONS}

An experiment was performed to find out the potential of using the commercial piezo plate in vibration energy harvesting. The results show that within a typical range of ambient vibration frequency (below $200 \mathrm{~Hz}$ ), peak power in mil- liwatts can be extracted. An output peak power of $1.5 \mathrm{~mW}$ was achieved when the load resistor matched the equivalent impedance of the piezo structure. The results also show that at low acceleration and very low frequency of vibration $(10 \mathrm{~Hz})$, a peak-to-peak voltage of $8 \mathrm{~V}$ can be generated. The PEH can charge a $1000 \mu \mathrm{F}$ capacitor with $0.6 \mathrm{~V}$ after $1 \mathrm{~min}$. The study shows that the conventional and nonflexible PZT ceramics have the potential to extract energy from ambient vibration to provide enough power for low-power applications (e.g., portable electronics and wireless sensors).

Received 30 September 2020 Accepted 10 August 2021

\section{References}

1. Li H., Tian C. Deng Z. Energy harvesting from low frequency applications using piezoelectric materials. Applied Physics Reviews. 2014. Vol. 1. Article 041301. doi: 10.1063/1.4900845

2. Yan N. X., Basari A. A., Nawir N. Piezoelectric ceramic for energy harvesting system: a review. ARPN Journal of Engineering and Applied Sciences. 2018. Vol. 13. No. 22. P. 8755-8775.

3. Jiang L., Cheung R. Hedley J., Hassan M., Harris A. J., Burdess J. S., Mehregany M., Zorman C. A. SiC cantilever resonators with electrothermal actuation. Sensors and Actuators A: 
Physical. 2006. Vol. 128. No. 2. P. 376-386. doi: 10.1016/j.sna.2006.01.045

4. Wang S., et al. Energy harvesting with piezoelectric drum transducer. Applied Physics Letters. 2007. Vol. 90. Iss. 11. Article 113506. doi: $10.1063 / 1.2713357$

5. Palosaari J., Leinonen M., Juuti J., Hannu J., Jantunen H. Piezoelectric circular diaphragm with mechanically induced pre-stress for energy harvesting. Smart Materials and Structures. 2014. Vol. 23. No. 8. Article 085025. doi: 10.1088/09641726/23/8/085025.

6. Scalet T., Viana J. F., Arthur R., Arnold F. J. Experimental Evaluation of Piezoelectric Buzzers as Devices for Energy Harvesting. Brazilian Technology Symposium, August, 2018. Campinas-SP, Brazil.

7. Wang W., Yang T., Chen X., Yao X. Vibration energy harvesting using a piezoelectric circular diaphragm array. IEEE Transactions on Ultrasonics, Ferroelectrics, and Frequency Control. 2012. Vol. 59. No. 9. doi: 10.1109/TUFFC.2012.2422.

8. Chen X-R., Yang T-Q., Wang W., Yao X. Vibration energy harvesting with a clamped piezoelectric circular diaphragm. Ceramics International. 2012. Vol. 38. Supplement 1. P. S271-S274. doi: 10.1016/j.ceramint.2011.04.099.

9. Nguyen M. D., Nazeer H., Dekkers M., Blank D. H. A. Rijnders G. Optimized electrode coverage of membrane actuators based on epitaxial PZT thin films. Smart Materials and Structures. 2013. Vol. 22. No. 8. Article 085013. doi: 10.1088/0964-1726/22/8/085013.
Musaab Zarog

PJEZOELEKTRINĖ KERAMIKA, NAUDOJAMA APLINKOS VIBRACIJOS ENERGIJAI KAUPTI

\section{Santrauka}

Tiesioginė pjezoelektrinè konversija yra labai populiari išgaunant energiją iš mechaninio ịtempio. Nuolat matomas progresas kaupiant energiją iš mechaninès vibracijos. Straipsnyje pateikiami eksperimentiniu bandymų su pjezoelektrine apskrito plokštele, siekiant ịvertinti elektros energiją, gautą pjezoelektrinès konversijos metu esant mažam pagreičiui ir ịvairiems aplinkos vibracijos dažniams, rezultatai. Eksperimentinè analizè parodè pigių pjezoelektrinių diafragmų panaudojimo potencialą energijai kaupti iš aplinkos vibracijos. Kai buvo mažas pagreitis $\left(5,36 \mathrm{~m} / \mathrm{s}^{2}\right)$, vibracijos dažnis keistas $10-200 \mathrm{~Hz}$ intervale ir išmatuota gauta energija. Esant labai mažai dinaminei jègai (mažiau nei $0,06 \mathrm{~N}$ ), 1,5 mW išèjimo galia buvo gauta naudojant $8,5 \mathrm{~mm}$ būgninị kaupiklị, kurio apkrovos varža $17,8 \mathrm{k} \Omega$, kai dažnis $173 \mathrm{~Hz}$.

Raktažodžiai: vibracijos energija, diafragma, PZT, mechaninè vibracija, keramika, vibracijos dažnis, rezonansas, visos bangos lygintuvas 